Department of Anatomy (Prof. T. Fujita), University of Niigata School of Medicine, Niigata, Japan; Department of Microbiology (Prof. A. Akisada), Kyushu Dental College ; and Department of Anatomy (Prof. H. Outi), University of Okayama School of Medicine

\title{
Scanning Electron Microscopy of the Skin Using Celluloid Impressions
}

\author{
Tsuneo Fujita, Junichi Tokunaga and Hajime Inoue \\ （藤田恒夫, 德永純一, 井上一)
}

Received December 25, 1968

The surface fine structure of the skin is one of the most suitable objects for scanning electron microscopy. The specimens may be prepared either with pieces obtained from the skin of cadavers or with surgically obtained tissues of pathological changes such as cancer (Fujita, Tokunaga and Inoue: unpublished). By using replicas, however, the ultrastructure of the skin in situ and in the living state can be observed without excising the skin. The present paper will briefly introduce a simple and widely applicable method using this idea.

\section{Material and Method}

A drop of amyl acetate or of a mixture of celluloid and amyl acetate was laid on a small celluloid plate (thickness : $0.4 \mathrm{~mm}$ )* and the latter immediately was attached to the skin to be examined. After being pressed with the finger to the skin for about one minute, the plate was detached. The impression or replica thus obtained was trimmed by scissors into a $1 \times 1 \mathrm{~cm}$ square, coated with carbon and gold in a vacuum evaporator and observed under a JSM-2 scanning electron microscope (Japan Electron Optics Laboratory Co. Ltd.). The finger belly and the ulnar part of the back of the hand of a 39-year-old man were used for impressions. The scar formed eight months after an operation in the nape of a 21-year-old woman also served in this study.

The photographs were printed both positively and negatively.

\section{Results}

The celluloid impressions obtained from different parts of the skin reproduced their surface structures finely enough for observation by scanning electron microscopy. Not only the form and arrangement of superficial cells of the epidermis, but also the delicate relief of the individual cells were clearly observed.

The cells on the surface of normal hand skin were thin and their sharp edge formed an oval, rhomboid or irregular outline (Fig. 1, 5). Their surface sometimes was divided into a few facets and partly provided with granular unevenness.

*Celluloid plates of a convenient size and different thicknesses together with amyl acetate and a mixture of celluloid and amyl acetate are sold as a set called "SUMP" (Suzuki's Universal MicroPrinting) by the SUMP Laboratory, 1618-25 Gakuen-Nishi, Kodaira-shi, Japan. 
T. Fujita, J. Tokunaga and H. Inoue:
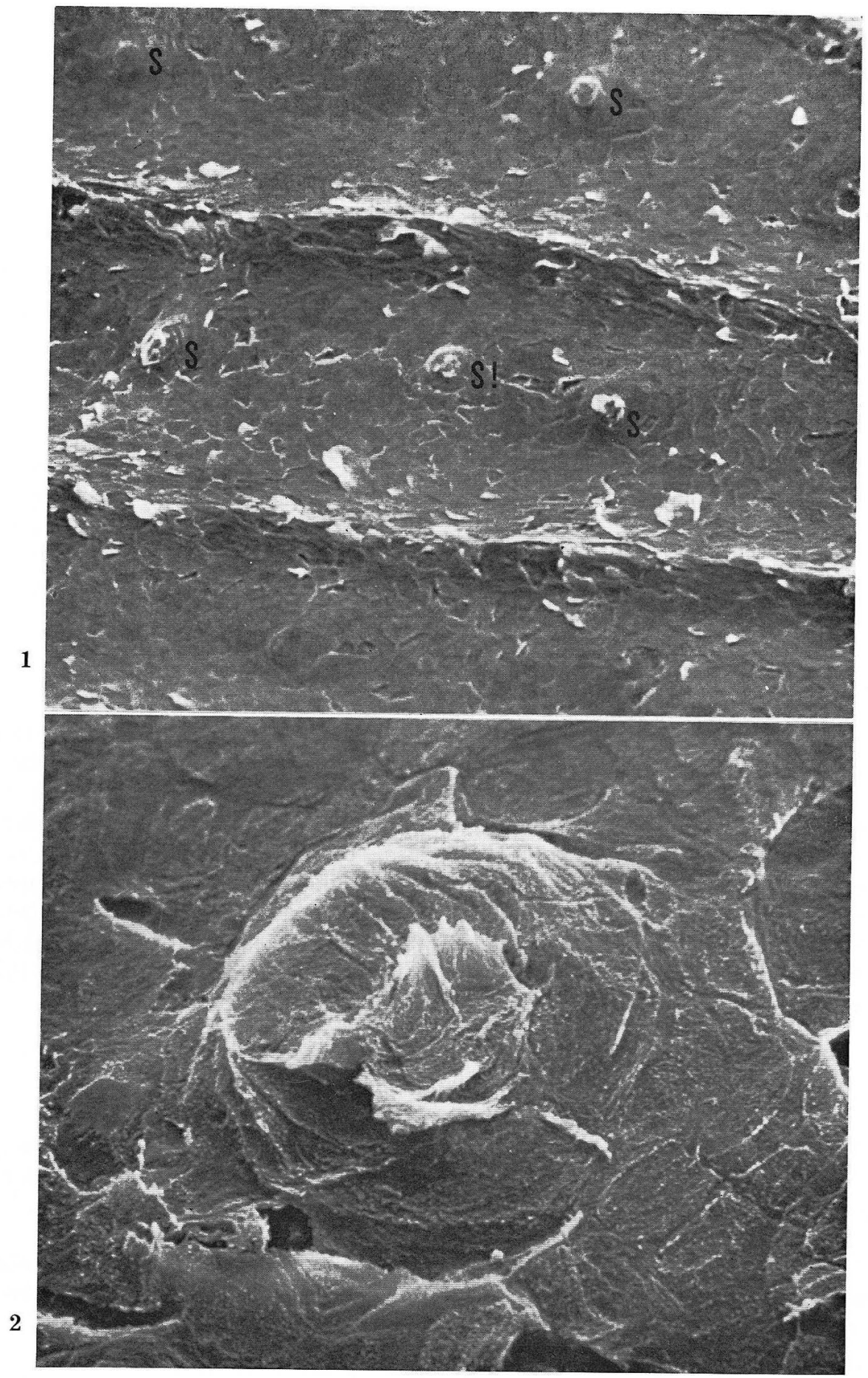

Fig. 1. A celluloid replica of the finger belly as seen under the scanning electron microscope. Note the furrows and crests of finger print and the orifices of sweat gland ducts $(S)$. Note also the scale-like appearance of epidcrmal cells. $\times 120$

Fig. 2. An orifice of sweat gland in the center of Figure $1(S$ !) in a higher magnification. $\times 1,200$ 


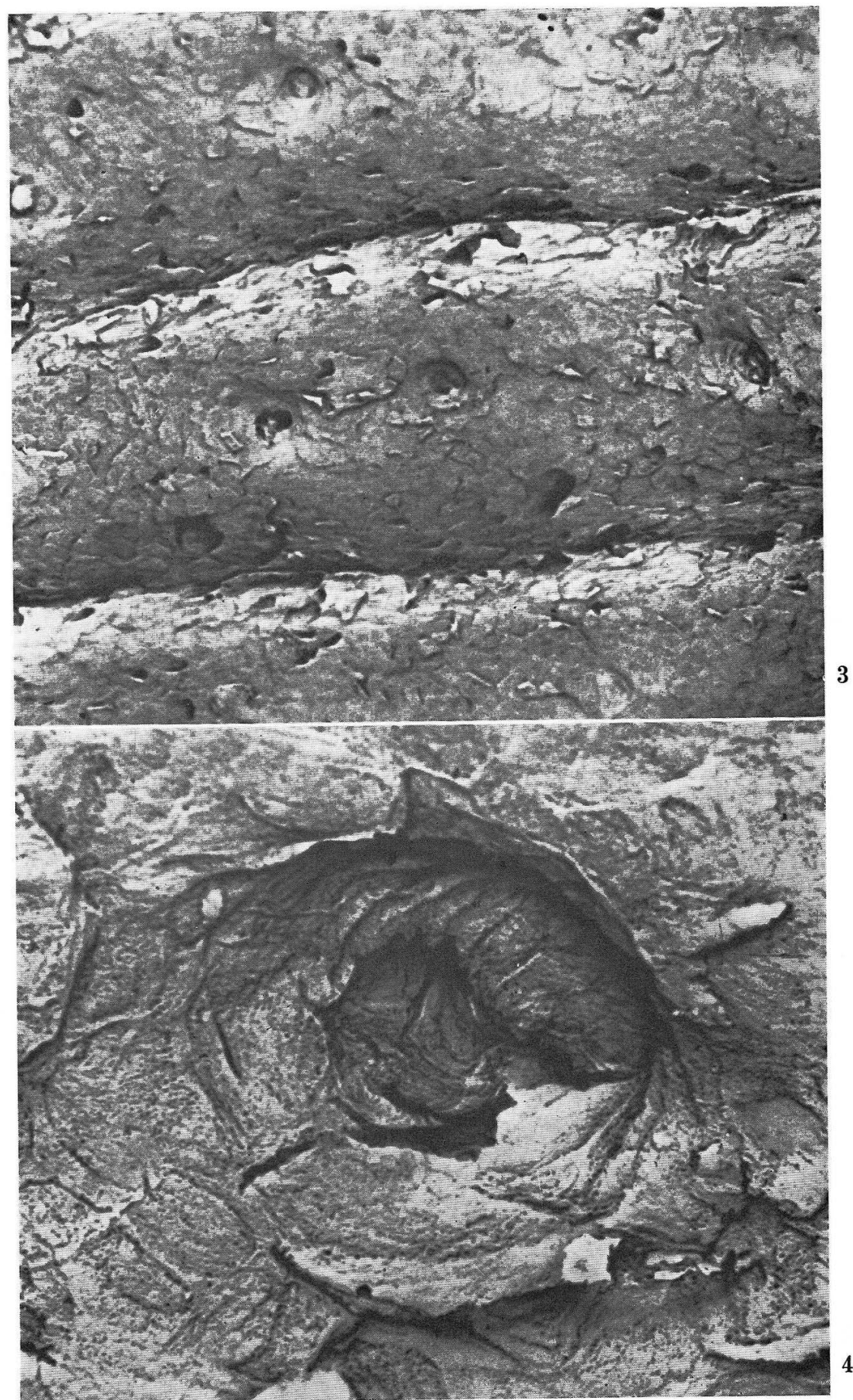

Fig. 3. A negative print of the photograph shown in Figure 1. The natural stereological appearance of the skin seems to have been approximately reproduced. $\times 120$

Fig. 4. A negative print corresponding to Figure 2. The fine structure of the cell surface can be more realistically observed than in the positive print. Note, however, that the form of the wall of the spiral duct is not correctly represented. $\times 1,200$ 


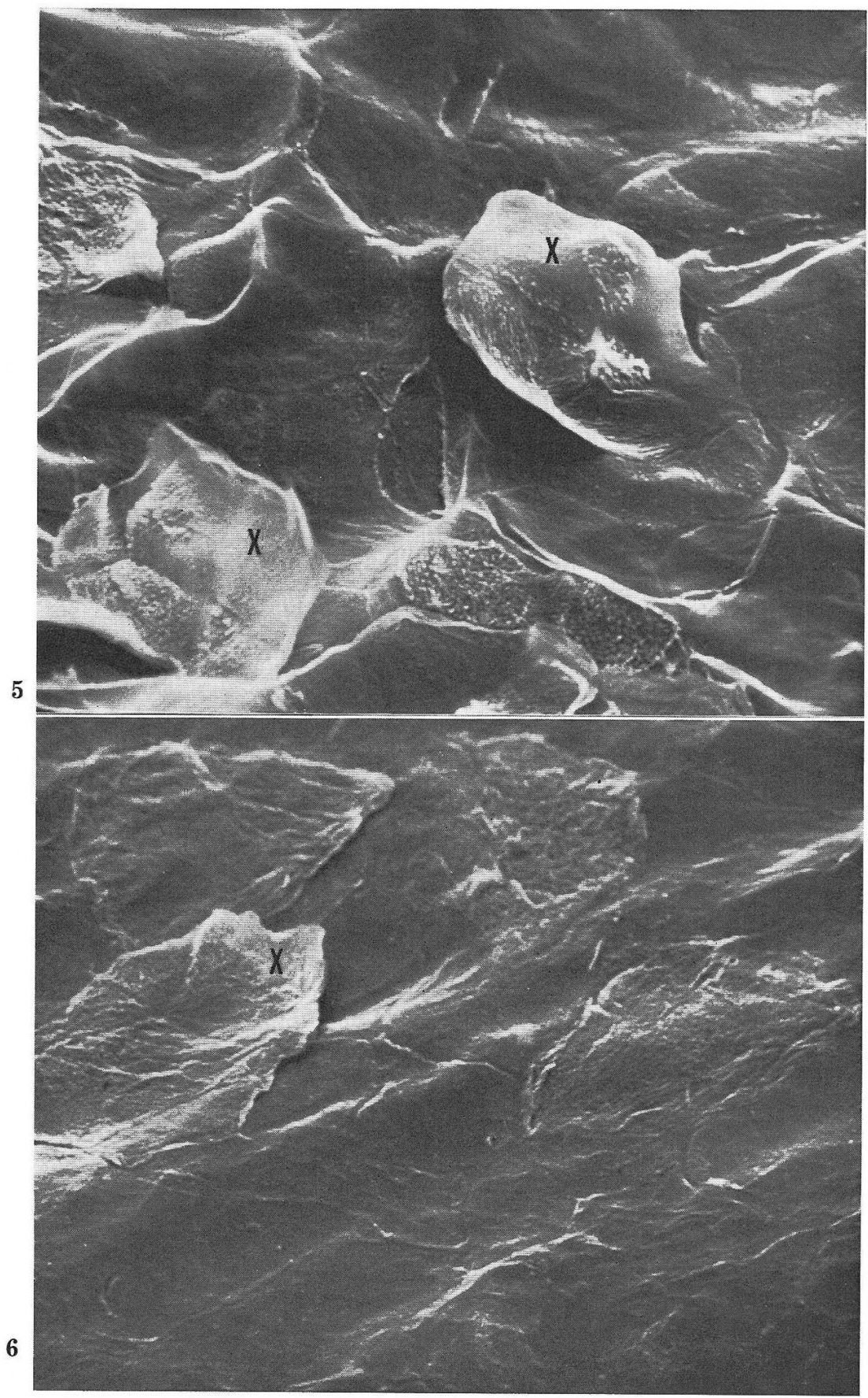

Fig. 5. A celluloid impression of the back of the hand. $X$ exfoliated cells attached on the celluloid plate. $\times 1,200$

Fig. 6. A celluloid replica of the surface cells in a scar. $\times 1,200$ 
The impressions from the finger belly showed the crests and furrows of the finger print beautifully. The superficial part of the duct lumen of sweat glands was, in its impression, represented by a flattened projection winding spirally (Fig. 2).

The surface of the scar showed an epidermal pavement whose cells were laid much flatter than in normal skin. The cell surface was also smooth except for slight wrinkles (Fig. 6).

It was inavoidable that a few cells exfoliated and attached themselves to the surface of the celluloid impression. This occurred more frequently in the back of the hand than in the finger belly and only rarely in the scar. The attached cells provided the opportunity to observe the back or basal side of the cells which were densely equipped with tiny granular projections.

When observed in the reverse or negative photographic prints, the relief of the skin surface was reproduced to some extent in its natural stereological relation (Fig. 3, 4). For instance the small pits in the epithelial cell surface came to appear realistically as such. On the other hand, the shadow parts in the impression pictures turned out to be of no meaning in their negatively printed pictures. The study of depressions in the surface such as the spiral structure of the gland duct mentioned above was impossible in these pictures.

\section{Discussion}

The celluloid impression method is useful for light microscopic study of the surface structures of various materials including the skin. In Japan it has been more widely used for the education of school children than for academic research. The present study revealed that this simplest type of replica method is fully valid for scanning electron microscopy because of its precise reproduction of fine, subcellular reliefs.

This method, however, has other merits besides its simpleness. It is free from deformation, such as shrinkage, of the structure which would be inavoidable if the skin is excised, fixed, dehydrated and directly observed under the scanning electron microscope.

CHAPMAN (1967) used a simple replica method for the scanning electron microscope study of botanical materials. On the surface of a leaf he placed a solution of polystyrene in a mixture of benzene and toluene and obtained a thin film with its impression. As compared with this, the thick, firm celluloid plates used in the present study seem much easier to handle and freer from artifacts which occur during metal evaporation and electron bombardment.

The exfoliation and attachment of some cells may increase the information obtained from the pure impressions, but they may be eliminated, if necessary, by chemical treatment of the impression plate.

The idea of printing negatively the photographs of impressions in order to visualize the natural relief of the material is not theoretically justified. This method, however, is effective as far as simple and low elevations and depressions in the material surface such as the finger print crests and tiny pits in the flat cell surface are concerned.

The present study indicates that the methodology introduced here can be applied not only for the study of the skin in normal and pathological states, but also 
more widely for the surface observation of various kinds of biological and nonbiological materials.

\section{Summary}

A celluloid plate dotted with a drop of amyl acetate was pressed to the skin. The impression thus obtained was coated with carbon and gold and observed under the scanning electron microscope. The cellular and subcellular structure of the skin surface could be clearly observed. The wide applicability of this simple method to dermatological and other studies was suggested.

\section{セルロイド印象による皮膚の走查電子鏡観察（内容自抄）}

酢酸アミルの 1 滴をつけたセルロイド板（スンプ）を皮膚に押しつけ，得られた印象 (レプリカ) にカーボンと金を蒸着して走査電子鏡で観察した。 この簡単な方法で皮膚 表面の細胞および細胞下のオーダーの構造が明瞭に観察できることが示され，皮膚科学 やそのほかの研究分野への応用の可能性が示唆された。

\section{Reference}

Chapman, B.: Polystyrene replicas for scanning reflexion microscopy. Nature 216 : 1347-1348 (1967). 